\title{
Bibliography
}

\section{Personal testimony}

Interviews conducted by the author:

Anna Adimira, Ngozi Aleme, Irico Aleme, Trevor Carter, Betty Hill, Donald Hinds, Jennifer Hosten, Frank Hunte, Sylvia John, Marcus Jordan, Olga Lope-Seale, Marvo Manning, Claudette Pickering

Recorded testimony archived at the British Library:

Dorothy Kuya interview, part of the Communist Party of Great Britain Biographical Project C1049/83/01-04

Diane Langford interview, part of the Hall-Carpenter Oral History Project (C456/107/01-03).

\section{Printed primary sources}

\section{MANUSCRIPT SOURCES}

Claudia Jones Memorial Collection 1935-38 (Schomberg Centre for Black Research, New York)

Norman Manley (National library of Jamaica)

Una Marson papers (National Library of Jamaica, Kingston, Jamaica)

\section{PHOTOGRAPHIC COLLECTIONS}

Beauty Contests (National Library of Jamaica)

Carnival Miscellaneous (National Archives of Trinidad and Tobago)

West Indies Committee (Institute for Commonwealth Studies, University of London)

SPECIAL COLLECTION

$\mathrm{H} / \mathrm{N}$ Beauties and Beauty Contestants. Jamaica and West Indies (National Library of Jamaica)

GOVERNMENT PUBLICATIONS

\section{Barbados}

Barbados Independence Celebrations (Jaycees-Government publication) 


\section{Jamaica}

Jamaica Hansard: 1954-55 Session

Cabinet Submission: Government Assistance to Beauty Contest Sponsored by the Council on Afro-Jamaican Affairs. 18 June 1964, 1B/31/523-1964 (Jamaica Archives, Spanish Town, Jamaica)

Pamphlet of Rules Governing Jamaica Festival 1965 (Jamaican Government Stationers)

\section{Trinidad}

Legislative Council Paper No. 14, 4 February 1953

Trinidad Hansard: 1954-55, 1956-57, 1958-59, 1960-61 Sessions

Trinidad Carnival and Calypso 1960, 1961, 1962

\section{PAMPHLETS}

\section{Barbados}

The Nation's Second Anniversary Celebrations, 1968 (Jaycees)

The Nation's Third Anniversary Celebrations, 1969

Barbados Jaycees '70 Independence Queen Show

Queen of the Teens 1972

\section{Jamaica}

'Miss Jamaica' 1958 Beauty Contest Souvenir Programme (Jamaica Tourist Board)

\section{Trinidad}

Trinidad's Sensational Calypso Dance (Trinidad Tourist Board)

Carnival Souvenir Programme 1951, 1952, 1953, 1954, 1955. (Savannah Carnival Committee)

Dimanche Gras 1960, 1961, 1962, 1965 (Trinidad Carnival Development Committee) Carnival Queen Show 1964 (Trinidad Jaycees)

Souvenir Independence Day Celebration 1968, 1969

Trinidad Carnival: The World's Most Colourful Festival (1970)

Trinidad Carnival: The World's Most Colourful Festival (1971)

\section{NEWSPAPERS AND PERIODICALS}

Bajan, The

Barbados Advocate

Barbados Civil Service Association Monthly Newsletter

Barbados Jaycees Newsletter

Caribbean Post

$$
\Longleftarrow 185 \Longleftarrow
$$


Cosmopolitan

Daily Gleaner (Jamaica)

Ebony (USA)

Jamaican Housewife

Jamaica Journal

Jamaica Weekly Gleaner (London)

JOFFA (London)

Life (USA)

New Cosmopolitan

Newday

New York Age

Planter's Punch

Port of Spain Gazette

Spotlight

Star, The (Jamaica)

Tan (USA)

Time (USA)

Trinidad Guardian

Vanity

West Indian Gazette (London)

\section{UNPUBLISHED RESEARCH PAPERS}

De Freitas, Patricia, Playing Mas; The Construction and Deconstruction of National Identity in the Trinidad Carnival. PhD Thesis, McMaster University, 1994

Pasley, Victoria, Gender, Race and Class in Urban Trinidad: Representations in the Construction and Maintenance of the Gender Order 1960-1980. PhD Thesis, University of Houston, 1999

Vassell, Linette, Voluntary Women's Associations in Jamaica: The Jamaican Federation of Women. MPhil Thesis, University of the West Indies, 1993

\section{Published sources}

Abrahams, Peter, Jamaica: An Island Mosaic (London: HM Stationery Office, 1956) Abreu, M., Boa, S., Newton, M., Paton, D., Scully, P. and Sheller, M., in Diana Paton and Pamela Scully (eds), Gender and Slave Emancipation in the Atlantic World (Durham: Duke University Press, 2005)

Altink, Henrice, 'Respectability on Trial: Notions of Womanhood in Two Jamaican Trials in the Interwar Years', The Society for Caribbean Studies Annual Conference Papers Sandra Courtman (ed.) 4 (2003) www.scsonline. freeserve.co.uk/olvol4.html (accessed 10 November 2006)

'More Than Producers and Reproducers: Jamaican Slave Women's Dance and Song' in Sandra Courtman (ed.), Beyond the Blood, the Beach and the Banana: New Perspectives in Caribbean Studies (Kingston: Ian Randle Publishers, 2004) 
'The Misfortune of Being Black and Female: Black Feminist thought in Interwar Jamaica', Thirdspace 5(2) (2006)

'An American Race Laboratory: Jamaica, 1865-1940', Wadabagei 10(3) (2007)

Anthony, Michael, Parade of the Carnivals of Trinidad 1839-1989 (Port of Spain: Circle, 1989)

Bakhtin, M.M., Rabelais and His World trans. Helene Iswolksy (Bloomington: Indiana University Press, 1984)

Banet-Weiser, Sarah, The Most Beautiful Girl in the World: Beauty Pageants and National Identity (Berkeley: University of California Press, 1999)

Barnard, R. and Erasmus, Z., in Sarah Nuttall and Cheryl-Ann Michael (eds), Senses of Culture: South African Culture Studies (Oxford: Oxford University Press, 2000)

Barnes, Natasha, 'Face of a Nation; Race, Nationalisms and Identities in Jamaican Beauty Pageants', in Consuelo Lopez Springfield (ed.), Daughters of Caliban, Caribbean Women in the Twentieth Century (Bloomington: Indiana University Press, 1997)

_ 'Body Talk: Notes on Women and Spectacle in Contemporary Trinidad Carnival', Small Axe 4(7) (2000)

Cultural Conundrums: Gender, Race, Nation, and the Making of Caribbean Cultural Politics (Ann Arbor: University of Michigan Press, 2006)

Barriteau, Eudine, 'Theorising Gender Systems and the Project of Modernity in the Twentieth-Century Caribbean', Feminist Review 59(1) (1998)

Barry, Kathleen, M., Femininity in Flight: A History of Flight Attendants (Durham: Duke University Press, 2007)

Batson, D., Brereton, B., Elder, J.D., Martin, C., Schener, R. and Riggio, M.C., in Riggio, M.C. (ed.), Carnival: Culture in Action: the Trinidad Experience (New York and London: Routledge, 2004)

Beckles, Hilary, Black Rebellion in Barbados: The Struggle Against Slavery (Bridgetown: Carib Research, 1987)

- A History of Barbados: from Amerindian Settlement to Nation State (Cambridge: Cambridge University Press, 1990), p. 41

Beckles, H., Brereton, B., Johnson, H. and Watson K., in Howard Johnson and Karl Watson (eds), The White Minority in the Caribbean (Oxford: J Currey, 1998)

Bennett, Louise, 'Colonisation in Reverse' in James Proctor (ed.), Writing Black Britain: An Interdisciplinary Anthology (Manchester: Manchester University Press, 2000)

Besson J. and Momsen J. in Momsen J. (ed.), Women and Change in the Caribbean

(Kingston: Ian Randle, 1993)

Bhattacharyya, G., Mirza, H.S. and Weeks, D., in Mirza, H.S. (ed.), Black British Feminism: A Reader (London: Routledge, 1997)

Blackwelder, Julia Kirk, Styling Jim Crow; African-American Beauty Training

During Segregation (College Station: Texas A\&M University Press, 2003)

Blake, Evon, Beautiful Jamaica (Port Antonio: Jamaica, Vista Publications, 1978) 
Bogues, Anthony, 'Nationalism and Jamaican Political Thought', in Kathleen Montieth and Glen Richards (eds), Jamaica in Slavery and Freedom: History, Heritage and Culture (Mona: University of West Indies Press, 2002)

Bogues A., Satchell V., and Vassell, L., in Brian Moore and Swithin Wilmot (eds), Before and After 1865: Papers on Education, Politics and Regionalism in the Caribbean (Kingston: Ian Randle, 1988)

Bolland, Nigel O., The Politics of Labour in the British Caribbean (Kingston: Ian Randle, 2001)

Bourne, Stephen, Black in the British Frame: Black People in British Film and Television, 1896-1996 (London: Cassell, 1996)

Braithwaite, Lloyd, 'Social Stratification in Trinidad: A Preliminary Analysis', Social and Economic Studies 2(2-3) (1953)

Breiner, Laurence A., An Introduction to West Indian Poetry (Cambridge: Cambridge University Press, 1998)

Brereton, Bridget, Race Relations in Colonial Trinidad 1870-1900 (Cambridge: Cambridge University Press, 1979)

— A History of Modern Trinidad, 1783-1962 (Exeter: New Hampshire, Heinmann, 1981)

Broder, Erna, Perceptions of Caribbean Women: Towards a Documentation of Stereotypes (Cave Hill: University of the West Indies, 1982)

Brown, Aggrey, Colour, Class and Politics in Jamaica (New Brunswick: Transaction Books, 1979)

Brown, Wenzell, Angry Men-Laughing Men: The Caribbean Cauldron (New York: Greenberg, 1947)

Bryan, Patrick, The Jamaican People 1880-1902: Race, Class and Social Control (London: Macmillan, 1991)

Burton, Antoinette, 'Introduction', in Antoinette Burton (ed.), Gender, Sexuality and Colonial Modernities (New York and London: Routledge, 1999)

Butler, Judith, Gender Trouble: Feminism and the Subversion of Identity (New York and London: Routledge, 1999)

Cameron, Linda (ed.), The Story of the Gleaner: Memoires and Reminiscences (Kingston: The Gleaner Company Ltd, 2000)

Campbell, Carl, The Young Colonials: A Social History of Education in Trinidad and Tobago, 1834-1939 (Mona: The University of the West Indies Press, 1996)

Campbell, Susan, 'Carnival, Calypso, and Class Struggle in Nineteenth Century Trinidad', History Workshop Journal 26(1) (1988)

Carby H.V., Gilroy, B. and Tulloch, C. in Kwesi Owusu (ed.), Black British Culture and Society, A Text Reader (New York and London: Routledge, 2000)

Carter, B., Harris, C., Joshi S. and James W. in James W. and Harris, C. (eds), Inside Babylon: The Caribbean Diaspora in Britain (London: Verso, 1993)

Chamberlain, M., Empire and Nation Building in the Caribbean: Barbados 19371966 (Manchester: Manchester University Press, 2010) 
Cohen, Lizbeth, 'Citizens and Consumers in the United States in the Century of Mass Consumption', in Martin Daunton and Matthew Hilton, The Politics of Consumption: On Material Culture and Citizenship in Europe and America (Oxford: Berg, 2001)

Collins, Patricia Hill, Knowledge, Consciousness and the Politics of Empowerment (New York and London: Routledge, 200o)

Cooper, Carolyn, Noises in the Blood: Orality, Gender and the 'Vulgar' Body of Jamaican Popular Culture. (Warwick: Macmillan Caribbean, 1993)

'Editorial: Jamaican Popular Culture', Interventions 6 (2004)

-Caribbean Fashion Week: Remodelling Beauty in "Out of Many One" Jamaica', Fashion Theory 14(3) (2010), pp. 387-404

Cowley, John, Carnival, Canboulay and Calypso: Traditions in the Making (Cambridge: University of Cambridge Press, 1996)

Craig, Maxine Leeds, Ain't I a Beauty Queen? Black Women, Beauty, and the Politics of Race (Oxford: Oxford University Press, 2002)

Crenshaw K. and Morrison T., in Morrison T. (ed.), Raceing Justice and EnGendering Power: Essays on Anita Hill, Clarence Thomas and the Construction of Social Reality (New York: Pantheon, 1992)

Dabydeen, David, Gilmore John and Jones, Cecily (eds), The Oxford Companion to Black British History (Oxford: Oxford University Press, 2008)

Davidson, Julia O'Connell and Taylor Jacqueline Sanchez, 'Exploring the Demand for Sex Tourism' in Kamala Kempadoo (ed.), Sun, Sex, and Gold: Tourism and Sex Work in the Caribbean (Lanham: Rowman and Littlefield, 1999)

Davies, Carol Boyce, Left of Karl Marx: The Political Life of Black Communist Claudia Jones (Durham: Duke University Press, 2008)

- (ed.) Claudia Jones: Beyond Containment (Banbury, Oxfordshire: Ayebia Publishing, 2011)

Davis, Angela, Women Race and Class (London: The Women's Press, 1982)

De Boissiere R., Rum and Coca-Cola (Melbourne: Australasian Book Society, 1956)

- Crown Jewel (London: Picador, 1981)

De Freitas, Patricia, Playing Mas; The Construction and Deconstruction of National Identity in the Trinidad Carnival, Unpublished doctoral thesis, McMaster University, 1994

De Grazia, Victoria, Irresistible Empire: America's Advance Through Twentieth Centure Europe (Cambridge, Mass: Harvard University Press, 2005)

De Lima, Arthur, The De Limas of Frederick Street (Trinidad: Imprint Caribbean Ltd, 1981)

De Lisser, Herbert, Jane's Career (London: Heinemann, 1972)

Donnell, Alison, 'Una Marson; Feminism, Anti-Colonialism and a Forgotten Fight for Freedom', in Bill Schwarz (ed.), West Indian Intellectuals in Britain (Manchester: Manchester University Press, 2003)

Donnell, Alison and Welsh, Sarah Lawson (eds), The Routledge Reader in Caribbean Literature (London: Routledge, 1996) 
Downes, Aviston, 'Boys of Empire: Elite Education and the Construction of Hegemonic Masculinity in Barbados, 1875-1920', in Rhoda E. Reddock (ed.), Interrogating Caribbean Masculinities (Kingston: University of the West Indies Press, 2004)

DuBois, Laurent, A Colony of Citizens: Revolution and Slave Emancipation in the French Caribbean, 1781-1804 (Chapel Hill: University of North Carolina Press, 2004)

Duncan, Neville, C. and O'Brien, Kenneth, Women and Politics in Barbados, 1948-1981 (Cave Hill: University of the West Indies, 1983)

Edmondson, Belinda, 'Public Spectacles: Caribbean Women and the Politics of Public Performance', Small Axe 7(1) (2005)

Caribbean Middlebrow: Leisure, Culture and the Middle-Class (Ithaca, New York: Cornell University Press, 2009)

Edmondson B. and Smith F.L., in Belinda Edmondson (ed.), Caribbean Romances: The Politics of Regional Representation (Charlottesville: University Press of Virginia, 1999)

Espinet, C. and Pitts, H., Land of Calypso: The Origin and Development of Trinidad's Folk Song (Port of Spain: Guardian Commercial Printery, 1944)

Ezra, Elizabeth, The Colonial Unconscious: Race and Culture in Interwar France (Ithaca, New York: Cornell University Press, 2000)

Fanon, Frantz, Black Skin, White Masks (London: Pluto Press, 1986)

Fermor, Patrick Leigh, The Traveller's Tree: A Journey Through the Caribbean Islands (London: John Murray, 1950)

Flynn, Elizabeth Gurley, The Alderson Story: My Life as a Political Prisoner (New York: International Publishers, 1963)

Ford-Smith, Honor, 'Una Marson: Black Nationalist and Feminist Writer', Caribbean Quarterly 34(3,4) (1988)

'Unruly Virtues of the Spectacular: Performing Engendered Nationalisms in the UNIA in Jamaica', Interventions 6(1) (2004)

'Making White Ladies: Race, Gender and the Production of Identities in Late Colonial Jamaica', Resources for Feminist Research 23(4) (2005)

Franco, Jennifer, When the Ti-Marie Closes (Port of Spain: Franco, 2000)

Franco, Pamela, 'Dressing Up and Looking Good: Afro-Creole Female Maskers in Trinidad Carnival', African Arts 3(2) (1998)

'The "Unruly Woman" in Nineteenth Century Trinidad Carnival', Small Axe 7(1) (2000)

French, Joan, 'Colonial Policy Towards Women after the 1938 Uprising: The Case of Jamaica,' Caribbean Quarterly 34(1,2) (1988)

Gilroy, Paul The Black Atlantic: Modernity and Double Consciousness (London: Verso, 1993)

— (ed.) Black Britain: A Photographic History (London: Saqi, 2007)

Goldstein, Donna "Interracial" Sex and Racial Democracy in Brazil: Twin Concepts?' American Anthropologist 101 (1999)

Green, Garth, 'Marketing the Nation: Carnival and Tourism in Trinidad and Tobago', Critique of Anthropology 22 (2002) 
Gregg, Veronica Mae, 'How With this Rage shall Beauty Hold a Plea: The Writings of Miss Amy Beckford Bailey as Moral Education in the Era of Jamaican Nation Building', Small Axe 11(23) (2007)

Gundle, Stephen, Glamour: A History (Oxford: Oxford University Press, 2008) Haidarali, Laila, 'Polishing Brown Diamonds: African American Women, Popular Magazines, and the Advent of Modelling in Early Postwar America,' Journal of Women's History 17 (2) (2005)

Hall, Catherine, 'White Visions, Black Lives: The Free Villages of Jamaica,' History Workshop 6 (1993), pp. 100-132

- Civilising Subjects: Metropole and Colony in the English Imagination 1830-1867 (Cambridge: Polity, 2002)

— White Male Middle-Class: Explorations in Feminism and History (Cambridge: Polity Press, 2007)

Hall, Stuart 'Cultural Identity and Cinematic Representation', Black British Cultural Studies: A Reader, Houston A. Baker, Manthia Diawara, Ruth H, Lindeborg (eds) (Chicago: University of Chicago Press, 1996)

Hall, S. and Young, L., in Read, A. (eds), Fact of Blackness (London: Institute of Contemporary Arts, 1996)

Harris, Clive, 'Images of Blacks in Britain, 1930-1960', Race and Social Policy (London: Economic and Social Research Council, 1998)

Heuman, Gad, Between Black and White: Race, Politics and the Free Coloured Population in Jamaica 1792 to 1865 (Westport: Greenwood, 1981)

Higginbotham, Evelyn Brooks, 'African-American Women's History and the Metalanguage of Race', in Ruth-Ellen B. Jones and Barbara Laslett (eds), The Second Signs Reader: Feminist Scholarship, 1983-1996 (Chicago: The University of Chicago Press, 1996)

Hill, Donald, Calypso Callaloo: Early Carnival Music in Trinidad (Gainsville: University of Florida Press, 1993)

Hill, Errol, The Trinidad Carnival: Mandate for National Theatre (London: New Beacon, 1997)

Hinds, Donald, Journey to an Illusion: The West Indian in Britain (London: Heinemann, 1966)

'The West Indian Gazette: Claudia Jones and the Black Press in Britain,' Race and Class 50 (2008)

Hooks, Bell, Ain't I a Woman: Black Women and Feminism (Boston: South End Press, 1981)

— Black Looks: Race and Representation (London: Turnaround, 1992)

Iremonger, Lucille, Yes My Darling Daughter (London: Secker and Warburg, 1964) James, C.L.R., Beyond a Boundary (London: Stanley Paul, 1963)

_ 'Triumph' and 'The Case for West Indian Self-Government', in Anna Grimshaw (ed.), The C.L.R James Reader 1901-1989, (Oxford: Blackwell, 1992)

James, Winston, Holding Aloft the Banner of Ethiopia: Caribbean Radicalism in Early-Twentieth Century America (London: Verso, 1998)

Jarrett-Macauley, Delia, The Life of Una Marson. 1905-65 (Manchester: Manchester University Press, 1998) 
Johnson, Buzz, 'Biographical Notes', in Johnson B (ed.), I Think of My Mother: Notes on the Life and Times of Claudia Jones (London: Karia Press, 1985)

Johnson, Howard, "The "Jamaica 300" Celebrations of 1955: Commemoration in a Colonial Polity', Journal of Imperial and Commonwealth History 26(2) (1998)

Johnson, Michele A. and Moore, Brian L, Neither Led Nor Driven: Contesting British Cultural Imperialism in Jamaica 1865-1920 (Kingston: University of the West Indies Press, 2004)

'Married but not Parsoned: Attitudes to Conjugality in Jamaica, 1865-1920', in Gad Heuman and David Trotman (eds), Contesting Freedom: Control and Resistance in the Post-Emancipation Caribbean (London: Macmillan, 2005) Jones, Claudia, 'The Caribbean Community in Britain', Freedomways 4(2) (1964) 'An End to the Neglect of the Problems of the Negro Woman', in Johnson B (ed.), I Think of My Mother: Notes on the Life and Times of Claudia Jones (London: Karia Press, 1985)

Khan, A. and Segal, D., in Yelvington K.A. (ed.), Trinidad Ethnicity (Knoxville: University of Tennessee Press, 1993)

Kitch, Carolyn L., The Girl on the Magazine Cover: The Origins of Visual Stereotypes in American Mass Media (Chapel Hill: University of North Carolina Press, 2001)

Knight, F.W. and Palmer, C.A. (eds), The Modern Caribbean (Chapel Hill: University of North Carolina Press, 1989)

Kutzinski, Vera, Sugar's Secrets: Race and the Erotics of Cuban Nationalism (Charlottesville: University of Virginia Press, 1993)

Lai, Walton Look, The Chinese in the West Indies: A Documentary History (Kingston: University of the West Indies Press, 1998)

Lamming, George, The Emigrants (London: Joseph, 1954)

- In the Castle of My Skin (New York: Schocken Books, 1983)

The Pleasures of Exile (London: Allison and Busby, 1984)

Larsen, Nella, Passing (New York: The Modern Library, 2002)

Lewis, Gordon, The Growth of the Modern West Indies (London: MacGibbon and Kee, 1968)

Lewis, L., 'The Contestation of Race in Barbadian Society and the Camouflage of Conservatism', in Brian Meeks and Folke Lindahl (eds), New Caribbean Thought: A Reader (Mona: University of the West Indies Press, 2001)

Lynch, Roslyn, Gender Segregation in the Barbadian Labour Market, 1946-1980 (Mona: University of the West Indies, 1995)

McKay, Claude, Banana Bottom (Chatham: Chatham Bookseller, 1970)

McNay, Lois, Feminism and Foucault: Power, Gender and the Self (Cambridge: Polity Press, 1992)

Madsen, Deborah, 'Performing Community through the Feminine Body: The Beauty Pageant in Transnational Contexts; http://home.adm.unige.ch/ $\% 7$ Emadsen/Zurich_pageants.htm (accessed 25 July 2006)

Mama, Amina, Beyond the Masks: Race, Gender and Subjectivity (New York and London: Routledge, 1995) 
Marson, Una, The Moth and the Star (Kingston: published by the author, 1937) Massiah, Jocelyn, Employed Women in Barbados: A Demographic Profile, 1946-1970 (Cave Hill: University of the West Indies, 1984)

Meighoo, Kirk, Politics in a Half Made Society: Trinidad and Tobago 1925-2001 (Kingston: Ian Randle, 2003)

Mittelholzer, Edgar, A Morning at the Office (London: Heinemann, 1974)

Modleski, Tania, Studies in Entertainment: Critical Approaches to Mass Culture (Bloomington: Indiana Press, 1986)

Mohammed, Patricia, " "But Most of All Mi Love Mi Browning”: The Emergence in Eighteenth and Nineteenth Century Jamaica of the Mulatto Woman as Desired', Feminist Review 65(1) (2000)

'A Blueprint for Gender in Creole Trinidad: Exploring Gender Mythology through Calypsos of the 1920 s and 1930s', in Linden Lewis (ed.), The Culture of Gender and Sexuality in the Caribbean (Gainsville: University of Florida Press, 2003)

Moreno Figueroa, M.G. 'Displaced Looks: On Being Beautiful, Ordinary, Ugly or Insignificant: The Lived Experience of Beauty and Racism in Mexico,' Feminist Theory (forthcoming), 14(2)

Morgan, Jennifer, Labouring Women: Reproduction and Gender in New World Slavery (Philadelphia: University of Pennsylvania Press, 2004)

Munroe, Trevor, The Politics of Constitutional Decolonisation: Jamaica 1944-1962 (Mona: University of West Indies Press, 1983)

Neptune, Harvey, 'White Lies: Race and Sexuality in Occupied Trinidad', Journal of Colonialism and Colonial History 2 (2001) //E:|2.1neptune.html (accessed 24 June 2006)

Caliban and the Yankees: Trinidad and the United States Occupation (Chapel Hill: University of North Carolina Press, 2007)

Nettleford, Rex (ed.) Norman Washington Manley and the New Jamaica: Selected Speeches and Writings, 1938-68 (New York: Africana, 1971)

O'Rain, Rebecca Chiyoko King, Pure Beauty: Judging Race in Japanese American Beauty Pageants (Minneapolis: University of Minnesota Press, 2006)

Oxaal, Ivar, Black Intellectuals Come to Power: The Rise of Creole Nationalism in Trinidad and Tobago (Cambridge, Mass.: Schenkman Publishing Company, 1968)

Paton, Diana, No Bond But the Law: Punishment Race and Gender in Jamaican State Formation 1780-1870 (Durham: Duke University Press, 2004)

Paul, Kathleen, Whitewashing Britain: Race and Citizenship in the Postwar Era (Ithaca, New York: Cornell University Press, 1997)

Pearce, Richard 'Toni Morrison's Jazz: Negotiations of the African-American Beauty Culture', Narrative 6(3) (1998)

Pearse, Andrew, 'Carnival in Nineteenth Century Trinidad', Caribbean Quarterly $4(3,4)(1956)$

Peiss, Kathy, Hope in the Jar: The Making of America's Beauty Culture (New York: Metropolitan Book, 1998) 
Phillips, Edsil, 'The Development of the Tourist Industry in Barbados 1956-1980', in DeLisle Worrell (ed.), The Economy of Barbados, 1946-1980 (Bridgetown: Central Bank of Barbados, 1982)

Pilkington, Edward, Beyond the Mother Country: West Indians and the Notting Hill Riots (London: I.B Tauris \& Co. Ltd, 1988)

Pinha, Patricia, 'Afro-Aesthetics in Brazil', in Sarah Nuttall (ed.), Beautiful/Ugly: African and Diaspora Aesthetics (Durham: Duke University Press, 2006)

Powrie, Barbara, 'The Changing Attitude of the Coloured Middle Class Towards Carnival', Caribbean Quarterly 4(3,4) (1956)

Proudfoot, Mary McDonald, Britain and the United States in the Caribbean: A Comparative Study in Methods of Development (London: Faber and Faber, 1954)

Quevedo, Raymond (Atilla the Hun) Atilla's Kaiso: A Short Story of Trinidad Calypso (St Augustine: University of the West Indies, 1983)

Reddock, Rhoda, Women, Labour and Politics in Trinidad and Tobago: A History (London: Zed Books, 1994)

Richardson, Bonham C., Panama Money in Barbados 1900-1920 (Knoxville: University Tennessee Press, 1985)

Roach, Joseph, Cities of the Dead: Circum-Atlantic performance (New York: Columbia University Press, 1996)

Rohlehr, Gordon, Calypso and Society in Pre-Independence Trinidad (Port of Spain: Gordon Rohlehr, 1990)

Rooks, Noliwe, Hair Raising: Beauty, Culture and African American Women (New Brunswick NJ: Rutgers University Press, 1996)

L Ladies Pages: African American Women's Magazines and the Culture That Made Them (New Brunswick, NJ: Rutgers University Press, 2004)

Rosenberg, Leah, Nationalism and the Formation of Caribbean Literature (Basingstoke: Palgrave Macmillan, 2007)

Rowe, R., 'Glorifying the Jamaican Girl: The “Ten Types” - One People’ Beauty Contest, Racialized Femininities, and Jamaican Nationalism. Radical History Review 103 (2009), pp. 36-58

Ryan, Selwyn, Race and Nationalism in Trinidad and Tobago: A Study of Decolonisation in a Multicultural Society (Toronto: University of Toronto Press, 1972)

Salih, Sarah and Butler, Judith, 'Bodily Inscriptions, Performative Subversions', in Sara Salih and Judith Butler (eds), The Judith Butler Reader (Malden: Blackwell, 2004)

Sander, Richard, From Trinidad: An Anthology of early West Indian Writing (London: Hodder and Stoughton, 1978)

Schwarz, Bill, 'Claudia Jones and the West Indian Gazette: Reflections on the Emergence of Postcolonial Britain', Twentieth Century British History 14(3) (2003)

Segal, Daniel, A., 'Race and Colour in Pre-Independence Trinidad and Tobago', in Kevin Yelvington (ed.), Trinidad Ethnicity (Knoxville: University of Tennessee Press, 1993) 
Sheller, Mimi, 'Quasheba. Mother, Queen: Black Women's Public Leadership and Political Protest in Post-emancipation Jamaica, 1834-65', Slavery and Abolition 19(3) (1998)

Consuming the Caribbean: From Arawaks to Zombies (New York and London: Routledge, 2003)

Shepherd, Verene, 'Introduction', in Verene Shepherd and Glen Richards (eds), Questioning Creole: Creolisation Discourses in Caribbean Culture (Kingston: Ian Randle, 2002)

Sherwood, Marika, Claudia Jones: A Life in Exile (London: Lawrence and Wishart, 1999)

Silver, Steve, 'Who Killed My Brother?', Searchlight, May 2006. ww.searchlight magazine.com/index.php?link=template\&story $=164$ (accessed 4 November 2009)

Simey, TS, Welfare and Planning in the West Indies (Oxford: Clarendon Press, 1946)

Smith, Hope Munro, 'Performing Gender in the Trinidad Calypso', Latin American Music Review 25(1) (2004)

Stallybrass, Peter and White, Allon, The Politics and Poetics of Transgression (Ithaca, New York: Cornell University Press, 1986)

Stephens, Michelle, Black Empire: The Masculine Global Imaginary of Caribbean Intellectual in the United States, 1914-1962 (Durham: Duke University Press, 2005)

Tate, Shirley Ann, 'Black Beauty: Shade, Hair and Anti-racist Aesthetics', Ethnic and Racial Studies 30 (2007)

— Black Beauty: Aesthetics, Stylization, Politics (Farnham: Ashgate, 2009)

Thomas, Deborah, Modern Blackness: Nationalism, Globalization and the Politics of Culture in Jamaica (Durham: Duke University Press, 2004)

Thompson, Krista, 'Black Skin, Blue Eyes: Visualising Blackness in Jamaican Art, 1922-1944,' Small Axe 8(2) (2004)

Tyson, Jennifer, Claudia Jones Woman of Our Times 1915-1964 (London: Camden Black Sisters, 1988)

Vassell, Linette (ed.), Voices of Women in Jamaica, 1898-1939 (Mona: University of the West Indies, 1993)

'Women of the Masses: Daphne Campbell and "Left" Politics in Jamaica in the 1950s,' in Verene Shepherd, Bridget Brereton and Barbara Bailey (eds), Engendering History, Caribbean Women in Historical Perspective (Kingston: Ian Randle, 1995)

Walker, Susannah, 'Black is Profitable: The Commodification of the Afro 19601975', Enterprise and Society 1(3) (2000)

- Style and Status; Selling Beauty to African American Women (Lexington: University Press Kentucky, 2007)

Wallace, Elisabeth, The British Caribbean: From the Decline of Colonialism to the End of Federation (Toronto: University of Toronto Press, 1977)

Webster, Wendy, “"There'll Always Be an England”; Representations of Colonial Wars and Immigration, 1948-1968', Journal of British Studies 40(4) (2001) 
Western, John, A Passage to England: Barbadian Londoners Speak of Home (Minneapolis: University of Minnesota Press, 1992)

Weinbaum, Alys Eve et al. (eds), The Modern Girl Around the World: Consumption, Modernity and Globalisation (Durham: Duke University Press, 2008)

Williams, Megan E., 'The Crisis Cover Girl: Lena Horne, the NAACP, and Representations of African American Femininity, 1941-1945,' American Periodicals 16(2) (2006)

Willis, Susan, 'I Shop Therefore I Am: Is There a Place for Afro-American Culture in Commodity Culture?', in Robyn R. Warhol and Diane Price Herndl (eds), Feminisms: An Anthology of Literary Theory and Criticism (Basingstoke: Macmillan, 1997)

Wright, Michelle, Becoming Black: Creating Identity in the African Diaspora (Durham: Duke University Press, 2004)

Wrightman Fox R and Jackson Lears, TJ, 'Introduction' in Fox R and Lears TJ (eds), The Culture of Consumption: Critical Essays in American History (New York: Pantheon, 1983), pp. vii-xvii

Young, Lola, 'What is Black British Feminism?', Women: A Cultural Review 11 (2000), pp. 45-6o

Young, Robert, Colonial Desire: Hybridity in Theory, Culture and Race (New York and London: Routledge, 1995)

Zobel, Joseph, Black Shack Alley trans. Keith Warner (Washington DC: Three Continents Press, 1980) 